\title{
Retinoic acid stimulates IGF binding protein (IGFBP)-6 and depresses IGFBP-2 and IGFBP-4 in SK-N-SH human neuroblastoma cells
}

\author{
D Chambéry, B de Gallé and S Babajko
}

Institut National de la Santé et de la Recherche Médicale, Unité de Recherches sur la Régulation de la Croissance, Hôpital Saint Antoine, Paris 75571, France (Requests for offprints should be addressed to S Babajko, INSERM Unité 142, Hôpital Saint Antoine, 184 rue du Faubourg Saint Antoine, 75571 Paris Cedex 12 , France)

\begin{abstract}
Insulin-like growth factors (IGF-I and IGF-II) stimulate proliferation and differentiation in many cell types. In biological fluids, they associate non-covalently with highaffinity binding proteins (IGFBPs) which control their bioavailability and modulate their action. We previously demonstrated that IGFBP-2, -4 and -6 are intimately involved in the growth of cells derived from human neuroblastomas. Here, we have investigated the effects of retinoic acid (RA), which induces differentiation in these cells, on the expression of IGFBPs secreted by SK-N-SH neuroblastoma cells. Analysis of transcriptional activity of the IGFBP-2, -4 and -6 genes in isolated nuclei (run-on experiments) showed that RA increased the transcriptional activity of the IGFBP-6 gene, reduced that of the IGFBP4 gene and had no effect on that of the IGFBP-2 gene. Northern blot analysis following treatment with actinomycin D showed that RA increased the stability of
\end{abstract}

IGFBP- 6 mRNA by a factor of $2 \cdot 6$, decreased that of IGFBP- 2 mRNA by a factor of $2 \cdot 3$ and failed to affect IGFBP-4 mRNA. Treatment of cells with cycloheximide indicated the involvement of labile proteins in the stabilization of these mRNAs the expression of which could be under the control of RA. The transcriptional and/or post-transcriptional mechanisms by which RA regulates each of the IGFBPs produced by SK-N-SH cells are therefore different. Such regulation may also reflect the state of differentiation of the neuroblastoma cells. With RA-induced differentiation, IGFBP-6 is strongly stimulated, whereas IGFBP-2 and IGFBP-4 are severely depressed, which would suggest that each IGFBP plays a specific role. Moreover, this regulation seems tissue-specific because it is different in other cell types.

Journal of Endocrinology (1998) 159, 227-232

\section{Introduction}

Insulin-like growth factors-I and -II (IGF-I and -II) play an important role in proliferation, differentiation and transformation in a wide variety of cell types (Stewart \& Rotwein 1996, Werner \& LeRoith 1996) and they are actively involved in the development of the nervous system (Sara 1992, De Pablo \& De la Rosa 1995). Neuroblastomas are embryonic tumours derived from neural crest cells giving rise to the sympathetic nervous system and are generally seen in young children. IGFs are known to be directly involved in the proliferation and differentiation of cell lines derived from neuroblastomas, acting via autocrine and/or paracrine mechanisms (El-Badry et al. 1989, Burke \& Vuk-Pavlovic 1993, Meghani et al. 1993) and their effects being mediated via the type 1 IGF receptor (Martin et al. 1993). In all biological fluids, IGFs are non-covalently bound to highaffinity binding proteins (IGFBPs) which regulate their bioavailability and modulate their interactions with their target cells (Rechler 1993, Jones \& Clemmons 1995). To date, six distinct molecular species, IGFBP-1 to IGFBP-6, have been identified (Shimasaki \& Ling 1991, Jones \& Clemmons 1995) and four other proteins possessing sequence homologies with the IGFBPs, but binding IGFs with only weak affinity have recently been described (Swisshelm et al. 1995, Oh et al. 1996). Although they are produced ubiquitously, each IGFBP exhibits characteristic patterns of expression related to tissue of origin, stage of development and hormonal environment. Under basal conditions, human neuroblastoma cells secrete IGF-II (El-Badry et al. 1991) and among the IGFBPs, predominantly IGFBP-2, smaller amounts of IGFBP-4 (Bernardini et al. 1994, Babajko \& Binoux 1996) and traces of IGFBP-6. With the arrest of proliferation in these cells, there is an increase in IGFBP-6 expression, but decreases in IGFBP-2 and IGFBP-4 expression, suggesting that the ratio of IGFBP-2 and -4 to IGFBP-6 influences cell growth (Babajko \& Binoux 1996, Babajko et al. 1997). Similar association of IGFBP-6 expression and arrest of cell 
growth has been described in keratinocytes (Kato et al. 1995) and myoblasts (Ewton \& Florini 1995). With exposure to retinoic acid, cells begin to differentiate and changes occur in IGFBP expression: IGFBP-6 is increased (Babajko \& Binoux 1996, Gabbitas \& Canalis 1996, Zhou et al. 1996) and IGFBP-2 and -4 are depressed in neuroblastoma cells (Bernardini et al. 1994, Babajko \& Binoux 1996) and increased in other cell types (Glantschnig et al. 1996). Retinoic acid (RA) is a natural derivative of vitamin A (retinol) and plays a role in the growth and development of various embryonic tissues, particularly in the nervous system. Therapeutic uses for RA and its 9 cis-RA or 13 cis-RA derivatives are under study for the treatment of neuroblastomas (Khan et al. 1996) and, since IGFBPs appear to influence neuroblastoma cell growth, it seemed of interest to characterize the changes in their expression provoked by an agent known to induce differentiation.

\section{Materials and Methods}

\section{Cell culture}

The human neuroblastoma cell line, SK-N-SH (Ross et al. 1983), was kindly provided by J Bénard (Institut Gustave Roussy, Villejuif, France). Cells were grown in Dulbecco's modified Eagle's medium (DMEM) (Gibco-BRL, Paisley, Strathclyde, UK) supplemented with $10 \%$ heat-inactivated fetal calf serum in the presence of $100 \mathrm{IU} / \mathrm{ml}$ penicillin, $10 \mu \mathrm{g} / \mathrm{ml}$ gentamicin and $1 \mu \mathrm{g} / \mathrm{ml}$ amphotericin. Cultures were carried out in a humidified incubator at $37{ }^{\circ} \mathrm{C}$ with $5 \% \mathrm{CO}_{2}$ atmosphere. At the end of the exponential growth phase, cells were trypsinized using 0.05\% trypsin-EDTA (Difco, Detroit, MI, USA) and seeded in $10 \mathrm{~cm}$-diameter petri dishes at $2 \times 10^{6}$ cells $/$ dish. After $24 \mathrm{~h}$, the medium was discarded and the culture was continued in serum-free medium for a further $24 \mathrm{~h}$ with or without $1 \mu \mathrm{M}$ all-trans-retinoic acid (Sigma Chemical Company, St Louis, MO, USA). Thereafter, medium was renewed with or without $5 \mu \mathrm{g} / \mathrm{ml}$ actinomycin D, and/or $5 \mu \mathrm{g} / \mathrm{ml}$ cycloheximide (Sigma).

\section{Isolation of RNA and Northern blotting}

Total RNAs were extracted from frozen cells using the standard $\mathrm{CsCl}$ /guanidine isothiocyanate method (Maniatis et al. 1982). RNA concentrations were determined by spectrophotometry.

Forty micrograms total RNA were loaded onto 1.2\% agarose $/ 2 \cdot 2 \mathrm{M}$ formaldehyde gels, submitted to electrophoresis, stained with ethidium bromide, transferred to Hybond-C nylon membranes (Amersham, Little Chalfont, Bucks, UK) and covalently bound to the nylon by baking of the membranes at $80{ }^{\circ} \mathrm{C}$ for $2 \mathrm{~h}$. After $4 \mathrm{~h}$ pre-hybridization at $50{ }^{\circ} \mathrm{C}$ in $5 \times \mathrm{SSC}, 50 \%$ formamide,
$5 \times$ Denhardt, $50 \mathrm{mM}$ sodium phosphate, $\mathrm{pH} \mathrm{6.5}$, and $250 \mu \mathrm{g} / \mathrm{ml}$ sonicated salmon sperm DNA, the blots were hybridized to $3 \times 10^{6}$ c.p.m. $/ \mathrm{ml}^{32}$ P-labelled complementary DNA (cDNA) probe (h-IGFBP-2, -4 or $-6 \mathrm{cDNA}$ ) (Babajko \& Binoux 1996) (Multiprime DNA labelling system, Amersham) for $24 \mathrm{~h}$ at $50{ }^{\circ} \mathrm{C}$ in the same buffer plus $10 \%$ dextran sulphate. The Northern blots were washed twice for $15 \mathrm{~min}$ in $2 \times \mathrm{SSC}, 0 \cdot 1 \% \mathrm{SDS}$ at room temperature and once for $30 \mathrm{~min}$ in $0.5 \times \mathrm{SSC}, 0.5 \% \mathrm{SDS}$ at $65{ }^{\circ} \mathrm{C}$ and finally autoradiographed at $-80{ }^{\circ} \mathrm{C}$ with intensifying screens.

All Northern blot data shown are representative of at least three separate experiments.

\section{Nuclear extract preparation}

Nuclei were prepared according to Bresnick \& Felsenfeld (1993) from cells pre-cultured for $24 \mathrm{~h}$ with or without RA. Cells were trypsinized (Difco), then centrifuged for $10 \mathrm{~min}$ at $600 \mathrm{~g}$. The pellet was washed twice with 20 volumes PBS phosphate buffer (Difco), then resuspended in 1.5 volumes $10 \mathrm{mM}$ Tris- $\mathrm{HCl}, \mathrm{pH} 7 \cdot 5,10 \mathrm{mM} \mathrm{NaCl}$, $3 \mathrm{mM} \mathrm{MgCl} 2,0 \cdot 2 \%$ Nonidet P-40, $10 \mathrm{mM}$ dithiothreitol (DTT). The cells were lysed in a Type B Dounce potter (12 passages) and the nuclei recovered after centrifugation at $4{ }^{\circ} \mathrm{C}$ for $5 \mathrm{~min}$ at $1000 \mathrm{~g}$. They were rinsed in 1.5 volumes $10 \mathrm{mM}$ Tris- $\mathrm{HCl}, \mathrm{pH} 7 \cdot 5,10 \mathrm{mM} \mathrm{NaCl}, 3 \mathrm{mM}$ $\mathrm{MgCl}_{2}, 10 \mathrm{mM}$ DTT, collected by centrifugation for $5 \mathrm{~min}$ at $800 \mathrm{~g}$ and immediately resuspended in an equal volume of $20 \mathrm{mM}$ HEPES, pH 7·5, 25\% glycerol, $20 \mathrm{mM}$ $\mathrm{KCl}, 0 \cdot 2 \mathrm{mM}$ EDTA. Nuclei were stained with trypan blue and counted on a Malassez grid, divided into aliquots and stored in liquid nitrogen.

\section{Run-on experiments}

The technique was based on the method of Riol et al. (1992) modified according to Babajko et al. (1993). Nuclei $\left(5 \times 10^{7}\right)$ were resuspended in $100 \mu \mathrm{l} 20 \mathrm{mM}$ Tris $-\mathrm{HCl}$, $\mathrm{pH} 7.9,75 \mathrm{mM} \mathrm{NaCl}, 0.5 \mathrm{mM}$ EDTA, $40 \%$ glycerol, $0.85 \mathrm{mM}$ DTT, $0.125 \mathrm{mM}$ phenylmethylsulphonyl fluoride (PMSF), to which was added a buffer comprised of $100 \mathrm{mM}$ Tris- $\mathrm{HCl}, \quad \mathrm{pH} 7.9, \quad 50 \mathrm{mM} \mathrm{NaCl}, 0.4 \mathrm{mM}$ EDTA, $0.1 \mathrm{mM}$ PMSF, $1.2 \mathrm{mM}$ DTT, $350 \mathrm{mM}$ $\left(\mathrm{NH}_{4}\right)_{2} \mathrm{SO}_{4}, 1 \mathrm{mg} / \mathrm{ml}$ heparin (Sigma), $4 \mathrm{mM} \mathrm{MnCl}_{2}$, $10 \mathrm{mM}$ creatinine phosphate (Boehringer Mannheim, Indianapolis, IN, USA), $1 \mathrm{mM}$ ATP, CTP and GTP (Boehringer Mannheim). Transcription was initiated in the two-buffer mixture in the presence of $500 \mathrm{U} / \mathrm{ml}$ RNase inhibitor (Boehringer Mannheim) and $500 \mu \mathrm{Ci}$ $\left[\alpha-{ }^{32} \mathrm{P}\right]$ UTP $(800 \mathrm{Ci} / \mathrm{mmol})$ (Amersham) and incubation continued for $20 \mathrm{~min}$ at $30^{\circ} \mathrm{C}$. The reaction was stopped by incubation in the presence of $10 \mathrm{U} / \mu \mathrm{l}$ DNase I (Boehringer Mannheim) for $30 \mathrm{~min}$ at $37^{\circ} \mathrm{C}$, and $10 \mathrm{mg} / \mathrm{ml}$ Proteinase K (Boehringer Mannheim) for $30 \mathrm{~min}$ at $37^{\circ} \mathrm{C}$. The reaction medium was precipitated overnight at 
$-20{ }^{\circ} \mathrm{C}$ using $8 \mathrm{M}$ guanidine hydrochloride, $\mathrm{pH}$, $100 \mathrm{mg} / \mathrm{ml}$ tRNA (Boehringer Mannheim) and 100\% ethanol. The newly synthesized RNAs were purified three times by washing in $7 \mathrm{M}$ guanidine hydrochloride, $\mathrm{pH} 7,2 \mathrm{M}$ sodium acetate and 100\% ethanol, then quantified. The labelled RNAs were hybridized for $72 \mathrm{~h}$ at $45{ }^{\circ} \mathrm{C}$ in $50 \%$ formamide, $5 \times \mathrm{SSC}, 0 \cdot 1 \% \mathrm{SDS}$, $1 \times$ Denhardt with $1 \mu \mathrm{g}$ cDNA (IGFBP-2, -4 or -6 ) or $\mathrm{pT}_{7} \mathrm{~T}_{3}$ (controls) covalently bound to nitrocellulose filters (BA 85, 0.45 $\mu \mathrm{m}$; Schleicher and Schuell, Dassel, Germany). Finally, the filters were washed three times in $5 \times$ SSC for $30 \mathrm{~min}$ at room temperature, twice in $50 \%$ formamide, $5 \times \mathrm{SSC}, 0 \cdot 1 \% \mathrm{SDS}$ for $1 \mathrm{~h}$ at $50{ }^{\circ} \mathrm{C}$, twice in $2 \times$ SSC for $15 \mathrm{~min}$ at room temperature, once in $5 \times$ SSC with $10 \mathrm{mg} / \mathrm{ml} \mathrm{RNase} A$ for $45 \mathrm{~min}$ at $50{ }^{\circ} \mathrm{C}$, and lastly, once in $1 \times$ SSC, $0 \cdot 1 \%$ SDS (Boehringer Mannheim) for $30 \mathrm{~min}$ at $50{ }^{\circ} \mathrm{C}$. In general, autoradiograms were revealed after 24 or $48 \mathrm{~h}$ of exposure, and in some cases up to 7 days.

The intensity of the hybridization signal was determined by laser densitometry scanning. Non-specific hybridization to control filters $\left(\mathrm{pT}_{7} \mathrm{~T}_{3}\right)$ was subtracted in each case. Results are expressed as percentages of the hybridization of radiolabelled transcripts from untreated cells with the same membrane-bound probe. Data represent the mean \pm S.E.M. of five separate experiments. Unpaired Student's $t$-test was used for statistical analysis.

\section{Results}

Effects of $R A$ on the transcriptional activity of IGFBP-2, -4 and -6 genes

Earlier results from our laboratory had shown that RA markedly increases the amounts of IGFBP-6 mRNA and reduces IGFBP-2 and -4 mRNAs (Babajko \& Binoux 1996). It remained to be determined at what level RA intervenes. The transcription experiments on nuclei isolated from SK-N-SH cells yielded some insight into the effects of RA on the transcriptional regulation of the IGFBP-2, -4 and -6 genes. With the run-on technique, only in vitro elongation of nascent IGFBP-2, -4 and -6 RNA transcripts initiated in vivo could be measured, since the heparin added to the reaction mixture inhibits binding of additional molecules of RNA polymerase-II to the cap site of these genes (Bresnick \& Felsenfeld 1993). Transcription efficiency was strongly reduced by $0.5 \mu \mathrm{g} / \mathrm{ml}$ $\alpha$-amanitine which at this concentration preferentially inhibits RNA polymerase-II (not shown). Treatment with $1 \mu \mathrm{M}$ RA for $24 \mathrm{~h}$ reduced the transcriptional activity of the IGFBP-4 gene by a factor of $3 \cdot 3 \pm 0 \cdot 2 \quad(n=5)$, $P \leq 0 \cdot 03$, but increased that of the IGFBP-6 gene by a factor of $3 \cdot 1 \pm 0 \cdot 2 \quad(n=5), P \leq 0 \cdot 02$, as compared with those in control cells (treated with only $0 \cdot 01 \%$ dimethyl sulphoxide as solvent). The transcriptional activity of the IGFBP-2 gene was unaffected by RA $(1 \pm 0 \cdot 2, n=5)$, the
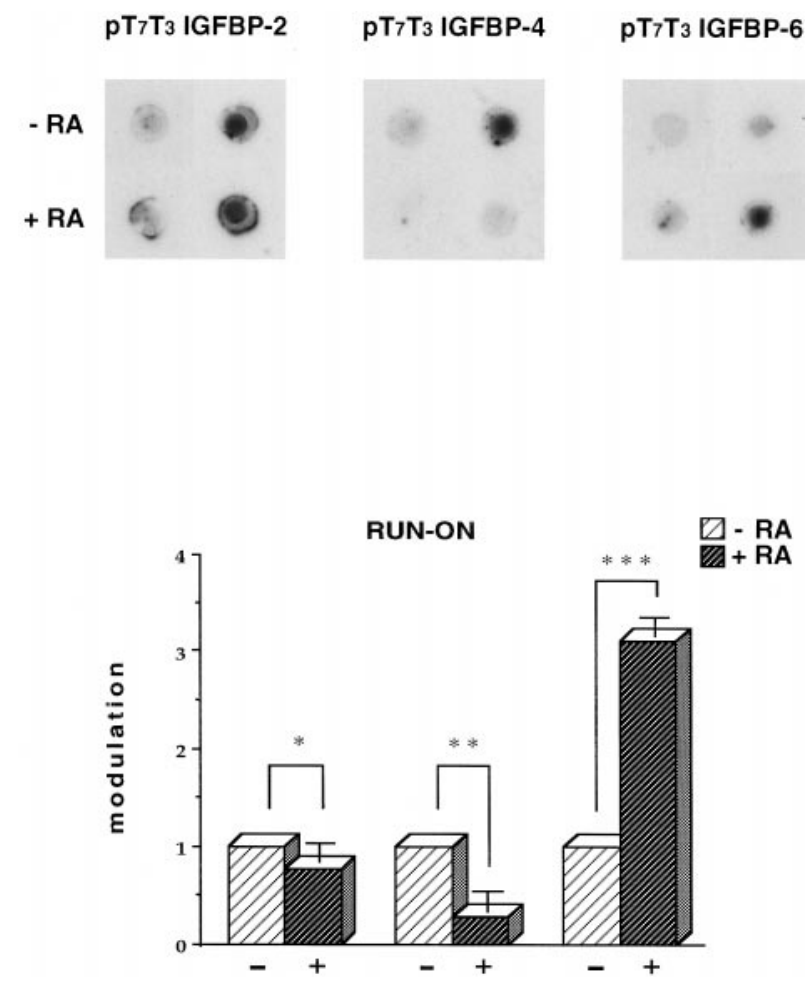

Figure 1 Run-on analysis of the effects of retinoic acid on the transcriptional activities of the genes coding for IGFBP-2, IGFBP-4 and IGFBP-6. In vitro transcription was investigated in $5 \times 10^{7}$ nuclei isolated from SK-N-SH cells treated or not with $1 \mu \mathrm{M}$ RA. Upper panel: autoradiogram of the hybridization spots. Lower panel: the intensity of hybridization signal was determined by laser densitometry scanning. Non-specific hybridization to control filters $\left(\mathrm{pT}_{7} \mathrm{~T}_{3}\right)$ was subtracted in each case. Results are expressed as percentages of the hybridization of radiolabelled transcripts from untreated cells with the same membrane-bound probe. Data represent the mean \pm S.E.M. of five separate experiments. Unpaired Student's $t$-test was used for statistical analysis $\left({ }^{\star} P \leq 0 \cdot 2\right.$,

$\left.{ }^{* *} P \leq 0 \cdot 03,{ }^{* * *} P \leq 0 \cdot 02\right)$.

$P \leq 0 \cdot 2$ value showing that the two groups of values were not significantly different (Fig. 1).

Effects of $R A$ on the stability of IGFBP-2, -4 and $-6 m R N A s$

The stability of the IGFBP-2, -4 and -6 mRNAs was investigated by treating the cells for $24 \mathrm{~h}$ with $5 \mu \mathrm{g} / \mathrm{ml}$ actinomycin D (a transcription inhibitor). Northern blot analyses showed that pre-treatment with $1 \mu \mathrm{M}$ RA for $24 \mathrm{~h}$ reduced the half-life of IGFBP-2 mRNA from 5.30 to $2.39 \mathrm{~h}$ and prolonged that of IGFBP-6 mRNA from 6.06 to $16.06 \mathrm{~h}$ (Fig. $2 \mathrm{~A}$ and Table 1). The half-life of IGFBP-4 mRNA was unaffected by RA, remaining simi$\operatorname{lar}(2.51 \mathrm{~h})$ to that under basal conditions $(3 \cdot 16 \mathrm{~h})$ (Fig. 2B and Table 1). 


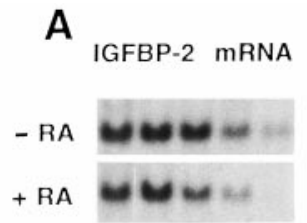

HOURS $\begin{array}{lllll}0 & 1 & 2 & 6 & 24\end{array}$

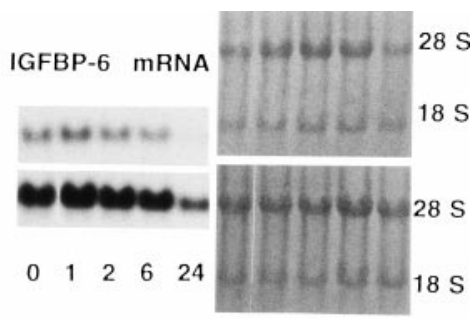

B

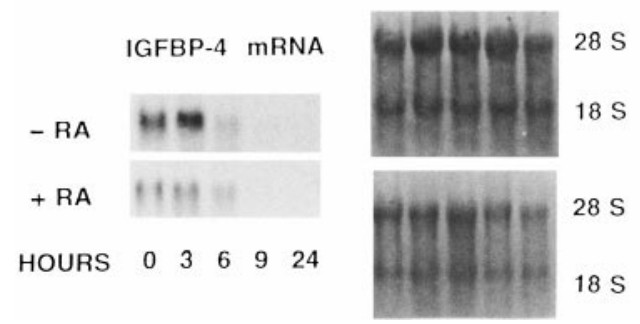

Figure 2 Northern blot analysis of the effects of RA on the half-lives of IGFBP-2, IGFBP-4 and IGFBP-6 mRNAs. SK-N-SH cells pre-treated or not with $1 \mu \mathrm{M}$ RA were incubated with $5 \mu \mathrm{g} / \mathrm{ml}$ actinomycin D (transcription inhibitor) for 1 to $24 \mathrm{~h}$. Forty micrograms total RNA were separated by agarose/formaldehyde gel electrophoresis, transferred to Hybond-C membranes and hybridized with ${ }^{32}$ P-labelled cDNA probes specific for each IGFBP. Autoradiograms of the hybridization spots are shown.

(A) RA-induced changes in the half-lives of IGFBP-2 and IGFBP-6 mRNAs. (B) Effects of RA on IGFBP-4 mRNA. Three independent experiments were carried out and these data are representative of a typical experiment.

\section{Role of labile proteins in $R A$-induced modulation of IGFBP-2, -4 and $-6 m R N A$ stability}

Following $3 \mathrm{~h}$ treatment with $5 \mu \mathrm{g} / \mathrm{ml}$ cycloheximide (a translation inhibitor), the amounts of IGFBP-2 and IGFBP-4 mRNA dropped to $55 \pm 12 \%$ and $42 \pm 3 \%$ of those under basal conditions, indicating that labile proteins are involved in the stabilization of these transcripts. IGFBP-6 mRNA was probably unaffected by cycloheximide and remained at very low levels.

Table 1 Half-lives (h) of IGFBP-2, IGFBP-4 and IGFBP-6 mRNAs. The intensity of the hybridization signal was determined by laser densitometry scanning standardized against 28S rRNA and compared with a curve representing signal intensity as a function of duration of actinomycin D treatment. One hundred percent signal was defined as the signal at the beginning of treatment and the estimation of half-life was based on the time when $50 \%$ signal remained. Data represent the mean \pm S.E.M. of three separate experiments

\begin{tabular}{|c|c|c|c|}
\hline & IGFBP-2 & IGFBP-4 & IGFBP-6 \\
\hline$-\mathrm{RA}$ & $5 \cdot 30 \pm 0 \cdot 30$ & $3 \cdot 16 \pm 0 \cdot 32$ & $6 \cdot 06 \pm 0 \cdot 29$ \\
\hline$+\mathrm{RA}$ & $2 \cdot 39 \pm 0 \cdot 20$ & $2 \cdot 51 \pm 0 \cdot 21$ & $16.06 \pm 0.37$ \\
\hline$P^{*}$ & 0.034 & 0.57 & $\leq 0 \cdot 001$ \\
\hline
\end{tabular}

*Unpaired Student's t-test.
IGFBP-2 mRNA

IGFBP-4 mRNA

IGFBP-6 mRNA

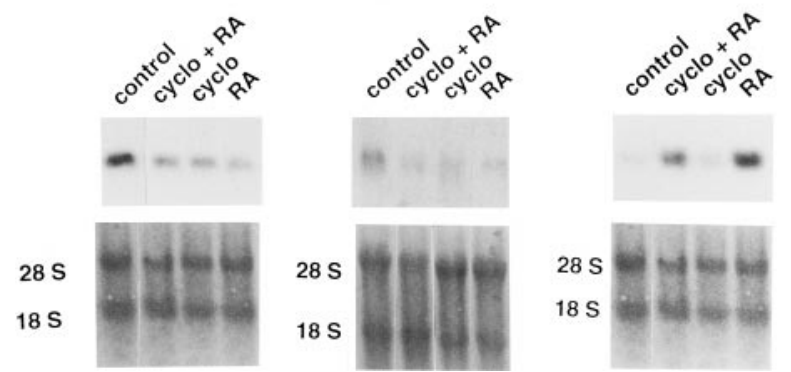

Figure 3 Northern blot analysis of the role of labile proteins in the stability of IGFBP-2, IGFBP-4 and IGFBP- 6 mRNAs in the presence of RA. SK-N-SH cells, pre-treated or not with $1 \mu \mathrm{M}$ RA, were incubated with $5 \mu \mathrm{g} / \mathrm{ml}$ cycloheximide (cyclo) (translation inhibitor) for $3 \mathrm{~h}$. Forty micrograms total RNA were hybridized with ${ }^{32}$ P-labelled cDNA probes specific to each IGFBP. Three independent experiments were carried out and these data are representative of a typical experiment.

With $24 \mathrm{~h}$ pre-treatment with RA, there was no additive effect with that of cycloheximide on the quantities of IGFBP-2 mRNA or IGFBP-4 mRNA levels, which remained the same or slightly decreased $(-55 \pm 2 \%$ versus control). Cycloheximide reduced RA-induced IGFBP-6 mRNA by $48 \pm 10 \%$ (Fig. 3).

\section{Discussion}

It is now well established that the IGFBPs may have IGF-dependent or -independent modulatory effects on cell proliferation. IGFBP-2 appears to be associated with growth, whereas IGFBP-6 expression seems to coincide with the arrest of proliferation (Babajko \& Binoux 1996, Babajko et al. 1997). No such clear-cut relationship has as yet been determined for IGFBP-4. Recent findings in our laboratory indicate that IGFBP-2 promotes tumorigenesis and that the incidence of neuroblastoma xenografts in nude mice is reduced in the presence of IGFBP-6 (Grellier et al. 1998, Menouny et al. 1998). RA is increasingly being investigated as a therapeutic agent for cancer and neuroblastomas in particular (Khan et al. 1996) and it seemed important to elucidate the mechanisms involved in its regulation of IGFBP expression. Earlier research in our laboratory showed that RA depresses IGFBP-2 and IGFBP-4 expression and increases the amounts of IGFBP-6 secreted by human neuroblastoma-derived cell lines (Babajko \& Binoux 1996). In the run-on experiments carried out in this study, RA enhanced the transcriptional activity of the gene coding for IGFBP-6, which would account for the effects seen on accumulation of the corresponding mRNA. The experiments with the transcription inhibitor, actinomycin $\mathrm{D}$, showed that RA prolonged the half-life of IGFBP-6 mRNA which, in 
concert with the stimulated transcription, would explain the marked increase in the quantities of IGFBP-6 mRNA. RA-induced modulations of IGFBP-6 expression apparently do not necessitate de novo synthesis, since RA was capable of inducing IGFBP-6 expression in the presence of cycloheximide, a translation inhibitor (not shown). Conversely, when cells were pretreated with RA, cycloheximide decreased IGFBP-6 mRNA levels, indicating that labile proteins stabilize IGFBP-6 mRNA whose expression may be controlled by RA. Nevertheless, although the half-life of IGFBP-6 mRNA was increased only $2 \cdot 6$-fold and transcriptional activity 3.1-fold, the amounts of mRNA were enriched by a factor of between 20 and 100 . It therefore seems probable that RA affects other regulatory pathways, such as nuclear RNA stability or maturation and/or transport, as has been reported for alkaline phosphatase mRNA (Zhou et al. 1994). Our results for IGFBP-6 are similar to those obtained for skeletal cells concerning transcriptional regulation but differ at the post-transcriptional level (Gabbitas \& Canalis 1996), suggesting that RA stimulation of IGFBP-6 is widespread among cell types, but that the levels of regulation may vary from one cell type to another.

RA was found to reduce the half-life of IGFBP2 mRNA, but not to affect the transcriptional activity of its gene, suggesting post-transcriptional regulation. This reduced half-life would account for the diminished expression observed. Labile proteins whose synthesis would be suppressed by RA were found to be involved in stabilizing IGFBP-2 mRNA. Unlike IGFBP-6 whose expression is stimulated by RA whichever the cell model investigated, IGFBP-4 appears to be subject to different types of regulation: RA stimulates its expression in osteoblasts (Glantschnig et al. 1996, Zhou et al. 1996) and in human breast carcinoma (Adamo et al. 1992, Sheikh et al. 1993), but depresses it in neuroblastoma cells. This is consistent with reports that RA may have opposite effects on IGFBP-2 expression which is depressed in osteoblasts, but enhanced in hepatocytes (Schmid et al. 1992). RA modulation of IGFBP-2 gene expression may therefore be cell type or tissue specific.

RA exerted its effects on IGFBP-4 expression at the transcriptional level, resulting in inhibited expression, although no retinoic acid receptor response element was found on the IGFBP-4 promoter. RA may influence the expression of transcription factors interacting with the IGFBP-4 promoter, exerting an indirect effect. To date, it is only in neuroblastoma cells that RA has been reported to inhibit IGFBP-4 expression (Bernardini et al. 1994, Babajko \& Binoux 1996). In breast cancer cell lines and osteoblast cells, RA stimulates IGFBP-4 expression (Adams 1993, Zhou et al. 1996). It would seem that in this case, RA modulation of IGFBP-4 gene expression is tissue specific, as is RA modulation of IGFBP-2 expression.

In conclusion, the effects of RA on IGFBP expression appear to contribute towards its effects on cell proliferation and differentiation. Our study shows that RA modulates IGFBP expression at both transcriptional and posttranscriptional levels. Under the influence of RA, the considerably stimulated IGFBP-6 would sequester IGF-II whose expression is also enhanced by RA, but for which IGFBP-6 has 100-fold affinity compared with IGF-I. The outcome would be reduced cell growth. Conversely, RA inhibits IGFBP-2 expression which otherwise accompanies proliferation and, in addition, its limited proteolysis releases free IGF-II, which stimulates cell growth (Menouny et al. 1997). The combination of stimulated IGFBP-6 and depressed IGFBP-2 and IGFBP-4 would therefore play a role in the arrest of proliferation provoked by RA.

\section{Acknowledgements}

We thank Michel Binoux for fruitful discussions and critical reading of the manuscript. This work was supported by INSERM, the Association pour la Recherche sur le Cancer and the Ligue Nationale contre le Cancer.

D Chambery is a recipient of a fellowship from the Ministère de l'Education Nationale, de l'Enseignement Supérieur et de la Recherche.

\section{References}

Adamo ML, Shao Z-M, Lanau F, Chen JC, Clemmons DR, Roberts CT, LeRoith D \& Fontana J 1992 Insulin-like growth factor-I (IGF-I) and retinoic acid modulation of IGF-binding proteins (IGFBPs): IGFBP-2, -3 , and -4 gene expression and protein secretion in a breast cancer cell line. Endocrinology 131 $1858-1866$.

Adams J 1993 Structure-activity and dose-reponse relationships in the neural and behavioral teratogenesis of retinoids. Neurotoxicology and Teratology 15 193-202.

Babajko S \& Binoux M 1996 Modulation by retinoic acid of insulin-like growth factor (IGF) and IGF binding protein expression in human SK-N-SH neuroblastoma cells. European Journal of Endocrinology 134 474-480.

Babajko S, Hardouin S, Segovia B, Groyer A \& Binoux M 1993 Expression of insulin-like growth factor binding protein-1 and -2 genes through the perinatal period in the rat. Endocrinology 132 2586-2592.

Babajko S, Leneuve P, Loret C \& Binoux M 1997 IGF-binding protein-6 is involved in growth inhibition in SH-SY5Y human neuroblastoma cells: its production is both IGF- and cell density-dependent. Journal of Endocrinology 152 221-227.

Bernardini S, Cianfarani S, Spagnoli A, Annicchiarico-Petruzzelli M, Melino G, Massoud R, Boscherini B, Finazzi-Agro A, Rosenfeld RG \& Federici G 1994 Expression and down-regulation by retinoic acid of IGF binding protein-2 and -4 in medium from human neuroblastoma cells. Journal of Neuroendocrinology 6 409-413.

Bresnick EH \& Felsenfeld G 1993 Evidence that the transcription factor USF is a component of the human $\beta$-globin locus control region heteromeric protein complex. Journal of Biological Chemistry 268 18824-18834.

Burke TW \& Vuk-Pavlovic S 1993 Insulin-like growth factor-I is a serum component stimulating growth of human neuroblastoma. In Vitro Cellular Development of Biology 29A 391-394. 
De Pablo F \& De la Rosa EJ 1995 The developing central nervous system: a scenario for the action of proinsulin, insulin and insulin-like growth factors. Trends in Neuroscience 18 143-150.

El-Badry OM, Romanus JA, Helman LJ, Cooper MJ, Rechler MM \& Israel MA 1989 Autonomous growth of a human neuroblastoma cell line is mediated by insulin-like growth factor-II. Journal of Clinical Investigation 84 829-839.

El-Badry OM, Helman LJ, Chatten J, Steinberg SM, Evans AE \& Israel MA 1991 Insulin-like growth factor-II mediated proliferation of human neuroblastoma. Journal of Clinical Investigation 87 648-657.

Ewton DZ \& Florini JR 1995 IGF binding proteins-4, -5 and -6 may play specialized roles during L6 myoblast proliferation and differentiation. Journal of Endocrinology 144 539-553.

Gabbitas B \& Canalis E 1996 Retinoic acid stimulates the transcription of insulin-like growth factor binding protein-6 in skeletal cells. Journal of Cellular Physiology 169 15-22.

Glantschnig H, Varga F \& Klaushofer K 1996 Thyroid hormone and retinoic acid induce the synthesis of insulin-like growth factorbinding protein-4 in mouse osteoblastic cells. Endocrinology 137 281-286.

Grellier P, de Gallé B \& Babajko S 1998 Expression of insulin-like growth factor (IGF) binding protein-6 complementary DNA alters neuroblastoma cell growth. Cancer Research 58 1670-1676.

Jones JI \& Clemmons DR 1995 Insulin-like growth factors and their binding proteins: biological actions. Endocrine Reviews 16 3-34.

Kato M, Ishizaki A, Hellman U, Wernstedt C, Kyogoku M, Miyazono K, Heldin C-H \& Funa K 1995 A human keratinocyte cell line produces two autocrine growth inhibitors, transforming growth factor- $\beta$ and insulin-like growth factor binding protein- 6 , in a calcium- and cell density-dependent manner. Journal of Biological Chemistry 270 12373-12379.

Khan AA, Villablanca JG, Reynolds CP \& Avramis VI 1996 Pharmacokinetic studies of 13-cis-retinoic acid in pediatric patients with neuroblastoma following bone marrow transplantation. Cancer Chemotherapy and Pharmacology 39 34-41.

Maniatis T, Fritsch EF \& Sambrook J 1982 Extraction, purification, and analysis of mRNA from eukaryotic cells. In Molecular Cloning, a Laboratory Manual, pp 188-209. Cold Spring Harbor: Cold Spring Harbor Laboratory Press.

Martin DM, Singleton JR, Meghani MA \& Feldman EL 1993 IGF receptor function and regulation in autocrine human neuroblastoma cell growth. Regulatory Peptides 48 225-232.

Meghani AA, Martin DM, Singleton JR \& Feldman EL 1993 Effects of serum and insulin-like growth factors on human neuroblastoma cell growth. Regulatory Peptides 48 217-224.

Menouny M, Binoux M \& Babajko S 1997 Role of insulin-like growth factor-binding protein-2 and its limited proteolysis in neuroblastoma cell proliferation: modulation by transforming growth factor- $\beta$ and retinoic acid. Endocrinology 138 683-690.

Menouny M, Binoux M \& Babajko S 1998 IGFBP-2 expression in a human cell line is associated with increased IGFBP-3 proteolysis, decreased IGFBP-1 expression, and increased tumorigenicity. International Journal of Cancer (In Press).

Oh Y, Nagalla SR, Yamanaka Y, Kim H-S, Wilson E \& Rosenfeld G 1996 Synthesis and characterization of insulin-like growth factor binding protein (IGFBP)-7. Journal of Biological Chemistry 271 30322-30325.

Rechler MM 1993 Insulin-like growth factor binding proteins. In Vitamins and Hormones, vol 47, pp 1-114. Ed DB McCormick. San Diego: Academic Press.

Riol H, Fages C \& Tardy M 1992 Transcriptional regulation of glial fibrilary acidic protein (GFAP) mRNA expression during post-natal development of mouse brain. Journal of Neuroscience Research 32 79-85.

Ross RA, Spengler BA \& Biedler JL 1983 Coordinate morphological and biochemical interconversion of human neuroblastoma cells. Journal of the National Cancer Institute 71 741-747.

Sara VR 1992 The role of insulin-like growth factors in the nervous system. In Insulin-like Growth Factors. Structure and Biological Functions, pp 80-109. Ed PN Schoffield. Oxford: Oxford University Press.

Schmid C, Schläpfer I, Waldvogel M, Meier PJ, Schwander J, Böni-Schnetzler M, Zapf J \& Froesch ER 1992 Differential regulation of insulin-like growth factor-binding protein (IGFBP)-2 mRNA in liver and bone cells by insulin and retinoic acid in vitro. FEBS Letters 303 205-209.

Sheikh MS, Shao Z-M, Hussain A, Chen J-C, Roberts CT, LeRoith D \& Fontana J 1993 Retinoic acid and estrogen modulation of insulin-like growth factor-binding protein-4 expression and the estrogen receptor status of human breast carcinoma cells. Biochemical and Biophysical Research Communications 193 1232-1235.

Shimasaki S \& Ling N 1991 Identification and molecular characterization of insulin-like growth factor binding proteins (IGFBP-1, -2, -3, -4, -5 and -6). Progress in Growth Factor Research $3243-266$.

Stewart CEH \& Rotwein P 1996 Growth, differentiation and survival: multiple physiological functions for insulin-like growth factors. Physiological Reviews 76 1005-1026.

Swisshelm K, Ryan K, Tsuchiya K \& Sager R 1995 Enhanced expression of an insulin growth factor-like binding protein (mac 25) in senescent human mammary epithelial cells and induced expression with retinoic acid. Proceedings of the National Academy of Sciences of the USA 92 4472-4476.

Werner H \& LeRoith D 1996 The role of the insulin-like growth factor system in human cancer. Advances in Cancer Research 68 183-222.

Zhou H, Manji SS, Findlay DM, Martin TJ, Heath JK \& Wah Ng K 1994 Novel action of retinoic acid - stabilization of newly synthesized alkaline phosphatase transcripts. Endocrinology 269 22433-22439.

Zhou Y, Mohan S, Linkhart TA, Baylink DJ \& Strong DD 1996 Retinoic acid regulates insulin-like growth factor binding protein expression in human osteoblast cells. Endocrinology 137 975-983.

Received 24 December 1997

Revised manuscript received 14 May 1998 Accepted 15 June 1998 